\title{
Influence of Variety and Plant Spacing on Yield and Yield Attributes of Roselle (Hibiscus sabdariffa L.)
}

\author{
Basazinew Degu Gebremedin*
}

\begin{abstract}
Ethiopian Institute of Agricultural Research, Wondo Genet Agricultural Research Center, P.O. Box: 198,
\end{abstract} Shashemene, Ethiopia

\begin{tabular}{|c|c|}
\hline Abstract & Article Information \\
\hline \multirow{12}{*}{$\begin{array}{l}\text { A field experiment was conducted to assess the influence of variety and plant spacing } \\
\text { on yield and yield attributes of roselle (Hibiscus sabdariffa L.) in } 2014 / 2015 \text { cropping } \\
\text { season at Wondo Genet Agricultural Research Center experimental site (at Wondo } \\
\text { Genet station). Six levels of plant spacing ( } 60 \times 30 \mathrm{~cm}, 60 \times 60 \mathrm{~cm}, 60 \times 90 \mathrm{~cm}, 90 \times 30 \\
\mathrm{~cm}, 90 \times 60 \mathrm{~cm} \text { and } 90 \times 90 \mathrm{~cm} \text { ) were evaluated using two varieties (WG-Hibiscus- } \\
\text { Jamaica and WG-Hibiscus-Sudan) on a plot size of } 15.12 \mathrm{~m}^{2}(3.6 \mathrm{~m} \text { length } \times 4.2 \mathrm{~m} \\
\text { width). The experimental design was a randomized complete block design in factorial } \\
\text { arrangement with } 12 \text { treatments in three replications. SAS (version 9) software was } \\
\text { used to compute the analysis of variance. The results revealed that varieties differed } \\
\text { markedly in most of the studied parameters. Of the two varieties tested, variety WG- } \\
\text { Hibiscus-Jamaican showed superior number of capsules/plant, fresh calyx yield/plant, } \\
\text { dry calyx yield/plant, seed yield/plant, total number of capsules/ha, total fresh calyx } \\
\text { yield/ha, total dry calyx yield/ha and total seed yield/ha. In contrast, variety WG- } \\
\text { Hibiscus-Sudan had heavier } 1000 \text { seed weight than variety WG-Hibiscus-Jamaican. All } \\
\text { of the studied parameters except } 1000 \text { seed weight were significantly influenced by } \\
\text { plant spacing. Moreover, number of capsules/plant, fresh and dry calyx yield/plant and } \\
\text { seed yield/plant were significantly influenced by interaction of variety and plant spacing. }\end{array}$} & History: \\
\hline & Received : 18-09-2015 \\
\hline & $: 14-12-2015$ \\
\hline & $\begin{array}{l}\text { Accepted : } 21-12-2015 \\
\text { Keywords: }\end{array}$ \\
\hline & Hibiscus sabdariffa L. \\
\hline & cing \\
\hline & WG-Hibiscus-Jamaica \\
\hline & WG-Hibiscus-Sudan \\
\hline & Fresh calyx yield \\
\hline & ${ }^{*}$ Corresponding Author: \\
\hline & Basazinew Degu Gebremedin \\
\hline & \\
\hline
\end{tabular}

\section{INTRODUCTION}

Roselle (Hibiscus sabdariffa L.) is one of the most important annual medicinal shrub that belongs to the family Malvaceae and it is locally known as "Karkade". This genus has more than 300 species among which, two species of $H$. sabdariffa and $H$. altissimia have been mentioned as an important species (Chen et al., 2002). It is believed to be native of India and later introduced to Malaysia where it is commonly cultivated and might have been carried at an early date to Africa (Morton, 1987). It is known in different countries by various common names, including roselle, razelle, sorrel, red sorrel, Jamaican sorrel, Indian sorrel, Guinea sorrel, sour-sour, and Queensland jelly plant (Mahadevan, 2009). In Englishspeaking countries it is known as roselle, Jamaican sorrel, red sorrel, Indian sorrel, rozelle hemp, natal sorrel and rosella. The Japanese name is rohzelu; also sabdriqa or lalambari in Urdu (Kays, 2011); and lal-ambari, patwa or laalambaar in Hindi (Kays, 2011). Roselle is an important cash crop in Western Sudan, particularly in Northern Kordofan State, especially in Elrahad and Um-Rawaba areas (El Naim et al., 2012).

The calyces are widely used to prepare herbal drink, cold and warm beverages, and for making jams and jellies (Tsai et al., 2002). In Africa, they are frequently cooked as a side dish and eaten with pulverized peanuts for stewing as sauce, for making a fine-textured sauce or juice (zobo), syrup, jam, marmalade, relish, chutney or jelly. The seeds are somewhat bitter but have been grounded to a meal for human food in Africa and have also been roasted as a substitute for coffee (Seiyaboh et al., 2013). Red calyces (based on $100 \mathrm{~g}$ dry weight) contain $6.4 \%$ protein, $79.3 \%$ carbohydrates, $5.1 \%$ fat, $2.7 \%$ crude fiber, and $6.5 \%$ ash (Nnam and Onyeke, 2003). Roselle is one of the most important and popular medicinal plant which has several properties. The leaves are emollient and are much used in Guinea as a diuretic, refrigerant and sedative (Anhwange et al., 2006) and used to sour the curry or "dal" preparation in Bangladesh as well as the young leaves are used as vegetable (Patil, 2004). The calyx, boiled in water is used as a drink in bilious attacks (Perry, 1980) and has also shown to lower blood pressure (McKay, 2010). The seeds of roselle are used as diuretic, laxative, tonic (Duke, 1985) and to treat debility (Perry, 1980).

In a study on the effect of sowing date and plant density on yield and agronomical traits of roselle in Zabol, Iran, it was reported that the increase in density from 4 to 8 plants $/ \mathrm{m}^{2}$, significantly decrease sepal weight and capsule number per plant, but capsule number per $\mathrm{m}^{2}$, sepal to capsule weight ratio, sepal yield and biological yield per unit area increased with the increase in plant density (Mir et al., 2011). Gholam and Moosavi (2012) studied the effect of sowing date and plant density on 
Basazinew Degu Gebremedin

yield and yield components of roselle in Birjan, Iran, it was reported that the increase in density from 8 to 13.3 plants $/ \mathrm{m}^{2}$, fruit number per plant, sepal yield per fruit and plant and single biomass decreased significantly by 29.8 , $24.4,39.1,55.4$ and $33.6 \%$, respectively, but fruit number $/ \mathrm{m}^{2}$ increased by $18.2 \%$.

In Ethiopia roselle is mainly used to produce healthy juice and herbal tea with full of flavor and tart, due to its high contents of vitamin $\mathrm{C}$ and anthocyanins that are found in the calyces. Roselle is predominantly produced by small scale farmers in their homestead garden. Ethiopia has a suitable environment for the production of roselle. But, there are limited findings regarding the modern production technology and to increase productivity to attract the industries or enterprises which are engaged in production and processing of roselle. This is due to lack of knowledge about the crop and limited supply of the crop products. Proper production technology is necessary for productivity of roselle to supply quality product to local or international markets, pharmaceuticals and beverage industries. The crop is produced in traditional management practices by small scale-farmers, depending on rainfall and poor agronomic practices. The main gap in production of the crop is poor agronomic practice such as improper spacing. Considering the enormous benefits of the roselle crop it is necessary to promote its growth and performance in terms of marketable and edible yields by growing it at an optimum spacing. The main yield-limiting factors are information or skill gap on how to produce this crop. Therefore, the objective of this study was to assess the influence of variety and plant spacing on yield and yield attributes of roselle.

\section{MATERIALS AND METHODS}

The experiment was conducted at Wondo Genet Agricultural Research Center experimental site in Southern Ethiopia during 2014/2015 cropping season. Wondo Genet is located between $7^{\circ} 19^{\prime} \mathrm{N}$ latitude and $38^{\circ} 38^{\prime} \mathrm{E}$ longitude; it is found at an altitude of 1780 m.a.s.I (meter above sea level) and receives mean annual rainfall of $1128 \mathrm{~mm}$ with minimum and maximum temperature of $11{ }^{\circ} \mathrm{C}$ and $26{ }^{\circ} \mathrm{C}$, respectively. The soil textural class of the experimental area is sandy loam with $\mathrm{pH}$ of 6.4 (Abayneh et al., 2006).

The seeds of the two varieties; namely, WG-HibiscusJamaica and WG-Hibiscus-Sudan were sown on spot directly on the experimental field after the land prepared well. The experiment consisted of six levels of plant spacing $(60 \times 30,60 \times 60,60 \times 90,90 \times 30,90 \times 60$ and $90 \times 90 \mathrm{~cm}$ ). The experiment was laid out in a factorial Randomized Complete Block Design (RCBD) with three replications. The plot size was $15.12 \mathrm{~m}^{2}$ (3.6 m length $\mathrm{x}$ $4.2 \mathrm{~m}$ width). The distance between each plot and replication was $1 \mathrm{~m}$ and $1.5 \mathrm{~m}$, respectively. Sowing was done on $18^{\text {th }}$ of September, 2014. Thinning was done progressively for the seedlings from spot sowing. The first thinning was done 10 days after sowing, to obtain 2 plants per spot. The final thinning was done 17 days after sowing, to have one plant per spot. The field was weeded twice a month starting from seeding until it was established well, the first one after two weeks from sowing and the second at four weeks later. And also the remaining weeding practices, hoeing and watering were made as required.
Sci. Technol. Arts Res. J., Oct-Dec 2015, 4(4): 25-30

Data on number of capsules/plant, fresh calyx yield/plant, dry calyx yield/plant, seed yield/plant, 1000 seed weight, number of capsules/ha, fresh calyx yield/ha, dry calyx yield/ha and seed yield/ha. To statically analyze the differences in characters caused by genotypic and spacing differences, five randomly selected samples were taken from each plot.

Mean values of all data for all characters measured were subjected to analysis of variance (ANOVA) using General Linear Model (GLM), statistical analysis software program (SAS inst., 2002). The LSD test was used to compare the mean separations at $5 \%$ probability level.

\section{RESULTS AND DISCUSSION}

\section{Number of Capsules per Plant}

Number of capsules/plant was significantly $(P<0.001)$ influenced by variety (Table 1). The higher number of capsules/plant (121.05) was recorded at variety WGHibiscus-Jamaica; while, the lower value (50.82) was recorded at variety WG-Hibiscus-Sudan (Table 2).

Likewise, plant spacing exerted a significant $(P<0.01)$ influence on number of capsules/plant (Table 1). The highest number of capsules/plant (121.21) was recorded at plant spacing of $90 \times 60 \mathrm{~cm}$; while, the lowest value (57.18) was recorded at plant spacing of $90 \times 30 \mathrm{~cm}$ (Table 2). Number of capsules/plant was increased at wider plant spacing due to less competition of plants for growth resources. Similar results were reported by Singh and yadav (1987) on sesame; ljoyah et al. (2010) on okra; Aluko et al. (2011) on kenaf and Jan et al. (2014) on sesame.

Interaction of variety with plant spacing had a significant $(P<0.01)$ influence on number of capsules/plant (Table 1). Planting variety WG-Hibiscus-Jamaica at plant spacing of $90 \times 60 \mathrm{~cm}$ recorded the highest number of capsules/plant (173.03); while, planting variety WGHibiscus-Sudan at plant spacing of $90 \times 90 \mathrm{~cm}$ was recorded the lowest value (30.42) (Table 4). In case of both varieties maximum number of capsules/plant was obtained at lower plant population density. This could be due to reduced competition of plants for light, nutrients, water and $\mathrm{CO}_{2}$. Supporting results were reported by Philip et al. (2010) on okra; Gholam and Moosavi (2012) on roselle.

\section{Fresh Calyx Yield per Plant}

Fresh calyx yield/plant was significantly $(P<0.001)$ influenced by variety (Table 1 ). The higher fresh calyx yield/plant $(373.23 \mathrm{~g})$ was recorded at variety WGHibiscus-Jamaica; while, the lower value (139.99 g) was recorded at variety WG-Hibiscus-Sudan (Table 2).

Similarly, plant spacing had a significant $(P<0.001)$ influence on fresh calyx yield/plant (Table 1). The highest fresh calyx yield/plant $(336 \mathrm{~g})$ was recorded at plant spacing of $90 \times 60 \mathrm{~cm}$; while, the lowest value $(163.03 \mathrm{~g})$ was recorded at plant spacing of $90 \times 30 \mathrm{~cm}$ (Table 2). Fresh calyx yield/plant increased at wider plant spacing. This could be due to the fact that in wider spacing there was less competition of plants for light, nutrient and water thereby plants could able to produced maximum fresh calyx yield/plant. Supporting result was reported by $\mathrm{El}$ Naim et al. (2012) who stated that calyces yield/plant increases gradually with increasing of plant spacing in roselle. 
Table 1: Analysis of variance for influence of plant spacing and variety on yield attributes of roselle

\begin{tabular}{lllllll}
\hline SOV & Replication & Variety & Spacing & Variety*Spacing & Error & CV \% \\
\hline DF & 2 & 1 & 5 & 5 & 22 & \\
NCPP & 2627.66 & $44380.46^{* * *}$ & $3099.39^{* *}$ & $2876.27^{* *}$ & 627.36 & 29.15 \\
FCYPP & 7314.67 & $489577.99^{* * *}$ & $30487.04^{* * *}$ & $41351.05^{* * *}$ & 4285.97 & 25.51 \\
DCYPP & 40.47 & $5677.64^{* * *}$ & $301.96^{* * *}$ & $462.82^{* * *}$ & 46.82 & 24.62 \\
SYPP & 435.17 & $10252.47^{* * *}$ & $838.94^{* *}$ & $667.92^{*}$ & 175.59 & 30.17 \\
TSW & 1.06 & $1870.36^{* * *}$ & $1.03 \mathrm{~ns}$ & $2.46 \mathrm{~ns}$ & 1.22 & 3.71 \\
NCPH & $1.76 \mathrm{E}+12$ & $2.1836745 \mathrm{E} 13^{* * *}$ & $4.8548252 \mathrm{E} 12^{* * *}$ & $259373043455 \mathrm{~ns}$ & $5.09 \mathrm{E}+11$ & 31.35 \\
FCYPH & 5177799.5 & $232986115.6^{\star * *}$ & $38839131.2^{* * *}$ & $6741657.1 \mathrm{~ns}$ & 2726611.9 & 24.59 \\
DCYPH & 15483.75 & $2832111.95^{* * *}$ & $538536.88^{* * *}$ & $99193.14 \mathrm{~ns}$ & 46626.06 & 29.21 \\
SYPH & 0.19 & $5.26^{* *}$ & $1.32^{* * *}$ & $0.036 \mathrm{~ns}$ & 0.15 & 33.13
\end{tabular}

Where, SOV = source of variance, NCPP $=$ Number of capsules/plant, FCYPP $=$ Fresh calyx yield/plant (g), DCYPP = Dry calyx yield plant/plant (g), SYPP $=$ Seed yield/plant $(\mathrm{g})$ and TSW $=1000$ seed weight $(\mathrm{g}), \mathrm{NCPH}=$ Number of capsules $/ \mathrm{ha}, \mathrm{FCYPH}=\mathrm{Fresh}$ calyx yield $(\mathrm{kg} / \mathrm{ha}), \mathrm{DCYPH}=$ Dry calyx yield $(\mathrm{kg} / \mathrm{ha}), \mathrm{SYPH}=$ Seed yield $(\mathrm{t} / \mathrm{ha}),{ }^{* * *}=$ significant at 0.001 level of probability, ${ }^{* *}=$ significant at 0.01 level of probability, ${ }^{*}=$ significant at 0.05 level of probability and $n s=$ non significant at 0.05 level of probability

Table 2: Effects of plant spacing and variety on some yield attributes of roselle

\begin{tabular}{ccccc}
\hline $\begin{array}{c}\text { Treatments and } \\
\text { statistics }\end{array}$ & $\begin{array}{c}\text { Number of } \\
\text { capsules/plant }\end{array}$ & $\begin{array}{c}\text { Fresh calyx } \\
\text { yield (g/plant) }\end{array}$ & $\begin{array}{c}\text { Dry calyx } \\
\text { yield (g/plant) }\end{array}$ & $\begin{array}{c}\text { Seed yield } \\
\text { (g/plant) }\end{array}$ \\
\hline Variety & $121.05^{\mathrm{a}}$ & $373.23^{\mathrm{a}}$ & $40.35^{\mathrm{a}}$ & $60.79^{\mathrm{a}}$ \\
V1 & $50.82^{\mathrm{b}}$ & $139.99^{\mathrm{b}}$ & $15.24^{\mathrm{b}}$ & $27.04^{\mathrm{b}}$ \\
V2 & 85.94 & 256.61 & 27.8 & 43.92 \\
\hline Mean & 17.32 & 45.26 & 4.73 & 9.16 \\
LSD 0.05 & & & & \\
\hline Plant spacing (cm) & $70.47^{\mathrm{bc}}$ & $206.97^{\mathrm{b}}$ & $23.29^{\mathrm{bc}}$ & $35.77^{\mathrm{bc}}$ \\
$60 \times 30$ & $77.08^{\mathrm{bc}}$ & $214.23^{\mathrm{b}}$ & $23.25^{\mathrm{bc}}$ & $38.72^{\mathrm{bc}}$ \\
$60 \times 60$ & $90.65^{\mathrm{b}}$ & $324.59^{\mathrm{a}}$ & $35.98^{\mathrm{a}}$ & $44.93^{\mathrm{bc}}$ \\
$60 \times 90$ & $57.18^{\mathrm{c}}$ & $163.03^{\mathrm{b}}$ & $19.22^{\mathrm{c}}$ & $31.18^{\mathrm{c}}$ \\
$90 \times 30$ & $121.21^{\mathrm{a}}$ & $336^{\mathrm{a}}$ & $36^{\mathrm{a}}$ & $64.46^{\mathrm{a}}$ \\
$90 \times 60$ & $99.03^{\text {ab }}$ & $294.85^{\mathrm{a}}$ & $29.13^{\mathrm{ab}}$ & $48.44^{\mathrm{b}}$ \\
\hline $90 \times 90$ & 85.94 & 256.61 & 14.36 & 43.92 \\
\hline Mean & 29.99 & 78.39 & 8.19 & 15.87 \\
\hline LSD 0.05 & 29.15 & 25.51 & 24.62 & 30.17 \\
\hline CV \% & & & &
\end{tabular}

Interaction of variety with plant spacing exerted a significant $(P<0.001)$ influence on fresh calyx yield/plant (Table 1). Planting variety WG-Hibiscus-Jamaica at plant spacing of $90 \times 60 \mathrm{~cm}$ recorded the highest fresh calyx yield/plant (563.69 g); while, planting variety WGHibiscus-Sudan at plant spacing of $90 \times 90 \mathrm{~cm}$ recorded the lowest value (89.48 g) (Table 4). Fresh calyx yield/plant increased at wider plant spacing in variety WGHibiscus-Jamaica (Table 4). This could be due to reduced competition of plants for light, nutrients and water. But in the case of WG-Hibiscus-Sudan, fresh calyx yield/plant increased gradually by increasing of plant spacing up to $60 \times 90 \mathrm{~cm}$. This could be due to favorable growth conditions of the spacing. Supporting result was reported by Gholam and Moosavi (2012) on roselle.

\section{Dry Calyx Yield per Plant}

Dry calyx yield/plant was significantly $(P<0.001)$ influenced by variety (Table 1 ). The higher dry calyx yield/plant (40.35 g) was recorded at variety WG-
Hibiscus-Jamaica; while, the lower value $(15.24 \mathrm{~g})$ was recorded at variety WG-Hibiscus-Sudan (Table 5).

Likewise, plant spacing had a significant $(P<0.001)$ influence on dry calyx yield/plant (Table 1). The highest dry calyx yield/plant $(36 \mathrm{~g})$ was recorded at plant spacing of $90 \times 60 \mathrm{~cm}$ followed by $60 \times 90 \mathrm{~cm}$; while, the lowest value $(19.22 \mathrm{~g})$ was recorded at plant spacing of $90 \times 30$ $\mathrm{cm}$ (Table 2). Dry calyx yield/plant increased wider plant spacing due to reduced competition of plants to light, nutrient, water and space. This result is in line with the finding of El Naim et al. (2012) who stated that calyces yield/plant increases gradually with increasing of plant spacing in roselle.

Likewise, interaction of variety with plant spacing exerted a significant $(P<0.001)$ influence on dry calyx yield/plant (Table 1). Planting variety WG-HibiscusJamaica at plant spacing of $90 \times 60 \mathrm{~cm}$ recorded the highest dry calyx yield/plant $(61.82 \mathrm{~g})$; while, planting 
Basazinew Degu Gebremedin

variety WG-Hibiscus-Sudan at plant spacing of $90 \times 90$ $\mathrm{cm}$ recorded the lowest value $(8.68 \mathrm{~g})$ (Table 4). Dry calyx yield/plant increased at wider plant spacing in variety WGHibiscus-Jamaica (Table 4). This could be due to reduced competition of plants for light, nutrients and water. But in the case of WG-Hibiscus-Sudan, dry calyx yield/plant increased gradually by increasing of plant spacing up to $60 \times 90 \mathrm{~cm}$. This could be due to favorable growth conditions of the spacing.

\section{Seed yield per plant}

Seed yield/plant was significantly $(P<0.001)$ influenced by variety (Table 1$)$. The higher seed yield/plant $(60.79 \mathrm{~g})$ was recorded at variety WG-Hibiscus-Jamaica; while, the lower value $(27.04 \mathrm{~g})$ was recorded at variety WGHibiscus-Sudan (Table 2).

Similarly, plant spacing had a significant $(P<0.01)$ influence on seed yield/plant (Table 1). The highest seed yield/plant $(64.46 \mathrm{~g})$ was recorded at plant spacing of $90 \mathrm{x}$ $60 \mathrm{~cm}$; while, the lowest value $(31.18 \mathrm{~g})$ was recorded at plant spacing of $90 \times 30 \mathrm{~cm}$ (Table 2). Seed yield/plant increased at wider plant spacing due to less competition of plants for light, water and nutrients.

Interaction of variety with plant spacing had a significant $(P<0.05)$ influence on seed yield/plant (Table 1). Planting variety WG-Hibiscus-Jamaica at plant spacing of $90 \times 90 \mathrm{~cm}$ recorded the highest seed yield/plant (83.92 g) followed by $90 \times 60 \mathrm{~cm}(81.17 \mathrm{~g})$; while, planting variety WG-Hibiscus-Sudan at plant spacing of $90 \times 90 \mathrm{~cm}$ was recorded the lowest value $(12.97 \mathrm{~g})$ (Table 5). Seed yield/plant increased linearly by increasing of plant spacing in WG-Hibiscus-Jamaica. But in the case of WGHibiscus-Sudan, seed yield/plant increased linearly by increasing of plant spacing from $60 \times 30 \mathrm{~cm}$ to $60 \times 60 \mathrm{~cm}$ and from $90 \times 30 \mathrm{~cm}$ to $90 \times 60 \mathrm{~cm}$. This could be due the smaller growth habit of the variety.

\section{0-Seed Weight}

1000 seed weight was significantly $(P<0.001)$ influenced by variety (Table 1$)$. The higher 1000-seed weight $(36.94 \mathrm{~g})$ was recorded at variety WG-HibiscusSudan; while, the lower value $(22.53 \mathrm{~g})$ was recorded at variety WG-Hibiscus-Jamaica (Table 3 ). This could be due to the difference in seed size and weight of the varieties.

\section{Number of Capsules per Hectare}

Number of capsules/ha was significantly $(P<0.001)$ influenced by variety (Table 1). The higher number of capsules/ha (3054187) was recorded at variety WGHibiscus-Jamaica; while, the lower value (1496527) was recorded at variety WG-Hibiscus-Sudan (Table 3).

Similarly, plant spacing exerted a significant $(P<0.001)$ influence on number of capsules/ha (Table 1). The highest number of capsules/ha (3914815) was recorded at plant spacing of $60 \times 30 \mathrm{~cm}$; while, the lowest value (1274803) was recorded at plant spacing of $90 \times 90 \mathrm{~cm}$ (Table 3). Number of capsules/ha was increased at closest plant spacing. This could be due to increased in number of plants per unit area attributed to an increase in number of capsules/ha. Number of capsules/ha increased
Sci. Technol. Arts Res. J., Oct-Dec 2015, 4(4): 25-30

by $45.31,56.61,42.04,39.87$ and $67.44 \%$ at plant spacing of $60 \times 30 \mathrm{~cm}$ as compared to plant spacing of $60 \times 60,60 \times 90,90 \times 30,90 \times 60$ and $90 \times 90 \mathrm{~cm}$, respectively.

\section{Fresh Calyx Yield per Hectare}

Fresh calyx yield/ha was significantly $(P<0.001)$ influenced by variety (Table 1$)$. The higher total fresh calyx yield/ha $(9258.6 \mathrm{~kg})$ was recorded at variety WGHibiscus-Jamaica; while, the lower value $(4170.7 \mathrm{~kg})$ was recorded at variety WG-Hibiscus-Sudan (Table 3 ).

Likewise, plant spacing exerted a significant $(P<0.001)$ influence on fresh calyx yield/ha (Table 1). The higher fresh calyx yield $(11498.1 \mathrm{~kg})$ was recorded at plant spacing of $60 \times 30 \mathrm{~cm}$; while, the lower value $(3833.4 \mathrm{~kg}$ ) was recorded at plant spacing of $90 \times 90 \mathrm{~cm}$ (Table 3). Fresh calyx yield/ha increased in closest plant spacing. This could be due to the fact that high population density per unit area attributed to the increase in fresh calyx yield/ha. Fresh calyx yield/ha increased by $48.25,47.79$, $43.74,43.18$ and $66.66 \%$ at plant spacing of $60 \times 30 \mathrm{~cm}$ as compared to plant spacing of $60 \times 60,60 \times 90,90 \times 30$, $90 \times 60$ and $90 \times 90 \mathrm{~cm}$, respectively.

\section{Dry Calyx Yield per Hectare}

Dry calyx yield/ha was significantly $(P<0.001)$ influenced by variety (Table 1 ). The higher dry calyx yield/ha $(1019.76 \mathrm{~kg})$ was recorded at variety WGHibiscus-Jamaica; while, the lower value $(458.8 \mathrm{~kg})$ was recorded at variety WG-Hibiscus-Sudan (Table 3 ).

Similarly, plant spacing exerted a significant $(P<0.001)$ influence on dry calyx yield/ha (Table 1). The highest dry calyx yield/ha $(1288.1 \mathrm{~kg})$ was recorded at plant spacing of $60 \times 30 \mathrm{~cm}$; while, the lowest value $(377.7 \mathrm{~kg})$ was recorded at inter-row spacing of $90 \mathrm{~cm}$ (Table 3). Dry calyx yield/ha increased in closer plant spacing. This could be due to the fact that high population density per unit area attributed to the increase in dry calyx yield/ha. Dry calyx yield/ha increased by $49.88,48.48,40.79,45.81$ and $70.68 \%$ at plant spacing of $60 \times 30 \mathrm{~cm}$ as compared to plant spacing of $60 \times 60,60 \times 90,90 \times 30,90 \times 60$ and $90 \times 90 \mathrm{~cm}$, respectively.

\section{Seed Yield per Hectare}

Seed yield/ha was significantly $(P<0.001)$ affected by variety (Table 1). The higher seed yield/ha (1.56 t) was recorded at variety WG-Hibiscus-Jamaica; while the lower value $(0.79 \mathrm{t})$ was recorded at variety WG-Hibiscus-Sudan (Table 3).

Likewise, plant spacing exerted a significant $(P<0.001)$ influence on seed yield/ha (Table 1). The highest seed yield/ha (1.99 t) was recorded at intra-row spacing of $60 \mathrm{x}$ $30 \mathrm{~cm}$; while, the lowest value $(0.63 \mathrm{t})$ was recorded at plant spacing of $90 \times 90 \mathrm{~cm}$ (Table 3 ). Total seed yield/ha increased in closest plant spacing. This could be due to the fact that high population density per unit area attributed to the increase in total seed yield/ha. Seed yield/ha increased by $45.73,58.29,37.69,35.68$ and $68.34 \%$ at plant spacing of $60 \times 30 \mathrm{~cm}$ as compared to plant spacing of $60 \times 60,60 \times 90,90 \times 30,90 \times 60$ and 90 x $90 \mathrm{~cm}$, respectively. 
Table 3: Effects of plant spacing and variety on some yield attributes of roselle

\begin{tabular}{cccccc}
\hline $\begin{array}{c}\text { Treatments } \\
\text { and statistics }\end{array}$ & $\begin{array}{c}\text { 1000 seed } \\
\text { weight } \mathbf{( g )}\end{array}$ & $\begin{array}{c}\text { Number of } \\
\text { capsules/ha }\end{array}$ & $\begin{array}{c}\text { Fresh calyx } \\
\text { yield (kg/ha) }\end{array}$ & $\begin{array}{c}\text { Dry calyx } \\
\text { yield (kg/ha) }\end{array}$ & $\begin{array}{c}\text { Seed yield } \\
\text { (t/ha) }\end{array}$ \\
\hline Variety & & & & & \\
V1 & $22.53^{\mathrm{b}}$ & $3054187^{\mathrm{a}}$ & $9258.6^{\mathrm{a}}$ & $1019.76^{\mathrm{a}}$ & $1.56^{\mathrm{a}}$ \\
V2 & $36.94^{\mathrm{a}}$ & $1496527^{\mathrm{b}}$ & $4170.7^{\mathrm{b}}$ & $458.80^{\mathrm{b}}$ & $0.79^{\mathrm{b}}$ \\
\hline Mean & 29.74 & 2275357 & 6714.65 & 739.28 & 1.18 \\
LSD 0.05 & 0.76 & 493113 & 1141.5 & 149.27 & 0.39 \\
\hline Plant spacing & & & & & \\
$60 \times 30$ & 29.29 & $3914815^{\mathrm{a}}$ & $11498.1^{\mathrm{a}}$ & $1288.1^{\mathrm{a}}$ & $1.99^{\mathrm{a}}$ \\
$60 \times 60$ & 29.41 & $2140972^{\mathrm{b}}$ & $5950.7^{\mathrm{b}}$ & $645.6^{\mathrm{b}}$ & $1.08^{\mathrm{bc}}$ \\
$60 \times 90$ & 29.53 & $1698747^{\mathrm{bc}}$ & $6003.4^{\mathrm{b}}$ & $663.6^{\mathrm{b}}$ & $0.83^{\mathrm{bc}}$ \\
$90 \times 30$ & 30.36 & $2268849^{\mathrm{b}}$ & $6469.3^{\mathrm{b}}$ & $762.7^{\mathrm{b}}$ & $1.24^{\mathrm{b}}$ \\
$90 \times 60$ & 29.76 & $2353954^{\mathrm{b}}$ & $6532.8^{\mathrm{b}}$ & $698^{\mathrm{b}}$ & $1.28^{\mathrm{b}}$ \\
$90 \times 90$ & 30.08 & $1274803^{\mathrm{c}}$ & $3833.4^{\mathrm{c}}$ & $377.7^{\mathrm{c}}$ & $0.63^{\mathrm{c}}$ \\
\hline Mean & 29.74 & 2275357 & 6714.65 & 739.28 & 1.18 \\
\hline LSD 0.05 & $\mathrm{~ns}$ & 854097 & 1977.1 & 258.54 & 0.47 \\
CV \% & 3.71 & 31.35 & 24.59 & 29.21 & 33.13 \\
\hline
\end{tabular}

Means followed by the same letter in the same column are not significantly different at $5 \%$ probability level using LSD test. ns= non significant at $5 \%$ probability level

Table 4: Interaction effects of plant spacing and variety on number of capsules/plant, fresh calyx yield ( $\mathrm{g} / \mathrm{plant}$ ) and dry calyx yield (g/plant) of roselle

\begin{tabular}{|c|c|c|c|c|c|c|c|c|c|}
\hline \multirow{3}{*}{$\begin{array}{c}\text { Plant } \\
\text { spacing } \\
\text { (cm) }\end{array}$} & \multicolumn{3}{|c|}{ Number of capsules/plant } & \multicolumn{3}{|c|}{ Fresh calyx yield (g/plant) } & \multicolumn{3}{|c|}{ Dry calyx yield (g/plant) } \\
\hline & \multicolumn{2}{|c|}{ Variety } & \multirow{2}{*}{ Mean } & \multicolumn{2}{|c|}{ Variety } & \multirow{2}{*}{ Mean } & \multicolumn{2}{|c|}{ Variety } & \multirow{2}{*}{ Mean } \\
\hline & V1 & V2 & & V1 & V2 & & V1 & V2 & \\
\hline $60 \times 30$ & $87.87^{\text {cde }}$ & $53.07^{\mathrm{ef}}$ & 70.47 & $258.45^{\mathrm{c}}$ & $155.48^{\mathrm{cde}}$ & 207 & $29.69^{C}$ & $16.69^{\mathrm{de}}$ & 23.19 \\
\hline $60 \times 60$ & $101.62^{\mathrm{cd}}$ & $52.53^{\mathrm{ef}}$ & 77.08 & $258.93^{c}$ & $169.52^{\mathrm{cde}}$ & 214.2 & $29.53^{c}$ & $16.97^{\mathrm{de}}$ & 23.25 \\
\hline $60 \times 90$ & $127.63^{\mathrm{bc}}$ & $53.67^{\mathrm{ef}}$ & 90.65 & $447.64^{\mathrm{b}}$ & $201.54^{\mathrm{cd}}$ & 324.6 & $48.17^{b}$ & $23.8^{\mathrm{cd}}$ & 35.99 \\
\hline $90 \times 30$ & $68.48^{\text {def }}$ & $45.87^{\mathrm{ef}}$ & 57.18 & $210.43^{c d}$ & $115.63^{\mathrm{de}}$ & 163 & $23.33^{\mathrm{cd}}$ & $15.11^{\text {de }}$ & 23.33 \\
\hline $90 \times 60$ & $173.03^{\mathrm{a}}$ & $69.39^{\text {def }}$ & 121.2 & $563.69^{a}$ & $108.31^{\mathrm{de}}$ & 336 & $61.82^{\mathrm{a}}$ & $10.19^{\mathrm{e}}$ & 36.01 \\
\hline $90 \times 90$ & $167.63^{a b}$ & $30.42^{f}$ & 99.03 & $500.22^{a b}$ & $89.48^{\mathrm{e}}$ & 294.9 & $49.57^{b}$ & $8.68^{\mathrm{e}}$ & 29.13 \\
\hline Mean & 121.04 & 50.83 & & 373.23 & 139.99 & & 40.35 & 15.27 & \\
\hline LSD $_{0.05}$ & \multicolumn{2}{|c|}{42.42} & & \multicolumn{2}{|c|}{110.86} & & \multicolumn{2}{|c|}{11.19} & \\
\hline CV (\%) & \multicolumn{2}{|c|}{29.15} & & \multicolumn{2}{|c|}{25.51} & & \multicolumn{2}{|c|}{24.62} & \\
\hline
\end{tabular}

Means followed by the same letter in the same column are not significantly different at $5 \%$ probability level using LSD test.

Table 5: Interaction effects of plant spacing and variety on seed yield (g/plant) of roselle

\begin{tabular}{|c|c|c|c|}
\hline \multirow{3}{*}{$\begin{array}{l}\text { Plant spacing } \\
\text { (cm) }\end{array}$} & \multicolumn{3}{|c|}{ Seed yield (g/plant) } \\
\hline & \multicolumn{2}{|c|}{ Variety } & \multirow[b]{2}{*}{ Mean } \\
\hline & V1 & V2 & \\
\hline $60 \times 30$ & $44.31^{\mathrm{cd}}$ & $27.22^{\text {cde }}$ & 35.77 \\
\hline $60 \times 60$ & $48.56^{\mathrm{bc}}$ & $28.89^{\text {cde }}$ & 38.73 \\
\hline $60 \times 90$ & $66.87^{\mathrm{ab}}$ & $23^{\mathrm{de}}$ & 44.94 \\
\hline $90 \times 30$ & $39.93^{\mathrm{cd}}$ & $22.43^{\text {de }}$ & 31.18 \\
\hline $90 \times 60$ & $81.17^{\mathrm{a}}$ & $47.75^{\mathrm{bc}}$ & 64.46 \\
\hline $90 \times 90$ & $83.92^{a}$ & $12.97^{\mathrm{e}}$ & 48.45 \\
\hline Mean & 60.79 & 27.04 & \\
\hline LSD $_{0.05}$ & \multicolumn{2}{|c|}{22.44} & \\
\hline CV (\%) & \multicolumn{2}{|c|}{30.17} & \\
\hline
\end{tabular}

Means followed by the same letter in the same column are not Significantly different at $5 \%$ probability level using LSD test 


\section{CONCLUSIONS}

From this finding, variety WG-Hibiscus-Jamaican showed greater number of capsules/plant, fresh calyx yield/plant, dry calyx yield/plant, seed yield/plant, number of capsules/ha, fresh calyx yield/ha, dry calyx yield/ha and seed yield/ha. In contrast, variety WG-Hibiscus-Sudan had heavier 1000 seed weight than variety WG-HibiscusJamaican. The highest fresh and dry calyx yield/ha were recorded when planting both varieties at plant spacing of $60 \times 30 \mathrm{~cm}$. At plant spacing of $60 \times 30 \mathrm{~cm}$ number of capsules/ha, fresh calyx yield/ha, dry calyx yield/ha and seed yield/ha were increased by $67.44,66.66,70.68$ and $68.34 \%$, respectively as compared to plant spacing of 90 $\times 90 \mathrm{~cm}$.

\section{Acknowledgments}

I would like to give my deepest thank to the Ethiopian Institute of Agricultural Research, Wondo Genet Agricultural Research Center for providing me with the chance to do this research. My special appreciation also goes to my wife Missus Endalamaw Shewaye who helped me a lot while carrying out the experiment and for her significant assistance during this work. Finally, my heartfelt appreciation also goes to all WGARC staffs in general for their unbounded moral support and encouragement during the study period.

\section{Conflict of Interest}

Conflict of interest none declared

\section{REFERENCES}

Abayneh Esayas., Demeke Tafesse and Ashenafi Ali (2006). Soils of Wondo Genet Agricultural Research Center. National Soil Research Center, 67 p.

Aluko, O.A., Agbaje, G.O and Olasoji, J.O. (2011). Effect of plant spacing on seed yield and yield components in kenaf (Hibiscus cannabinus) variety, Ifeken 400. African Journal of Plant Science 5(12): 718-721.

Anhwange, B.A., Ajibola, V.O., Okibe, F.G. (2006). Nutritive value and antinutritional factors in Hibiscus sabdariffa. Journal of Fisheries International 2:73-76.

Chen, C.C., Hsu, J.D., Wang, S.F., Chiang, H.C., Yang, M.Y and Kao, E.S. (2002). Hibiscus Sabdariffa extract inhibits the development of atherosclerosis in cholesterol-fed rabbits. Journal of Agricultural and Food Chemistry 5: $5472-5477$

Duke, J.A. and Ayensu, E.S. (1985). Medicinal plants of China. 2 vol. Reference Publications, Inc., Algonac, MI, USA.

El Naim, A.M., Khaliefa, E.H., Ibrahim, K.A., Ismaeil, F.M. and Zaied, M.B., 2012. Growth and Yield of Roselle (Hibiscus sabdariffa L.) as Influenced by Plant Population in Arid Tropic of Sudan under Rain-fed. International Journal of Agriculture and Forestry 2(3): 88-91

Gholam, S. and Moosavi, R. (2012). The effect of sowing date and plant density on yield and yield components of roselle. Journal of Medicinal Plants Research 6(9): 16271632

ljoyah, M.O., Unah, P.O. and Fanen, F.T. (2010). Response of okra (Abelmoschus esculentus L. Moench) to intra-row spacing in Makurdi, Nigeria. Agriculture and Biology Journal of North America 1(6):1328-1332

Jan, A., Ali, S., Adail, M. and Khan, A. (2014). Growth and yield components of sesame (Sesamum indicum L.) as influenced by phosphorus levels under different row spacing. Journal of Environment and Earth Science 4(22): 150-154

Kays, S.J. (2011). Cultivated vegetables of the world: A multilingual onomasticon. University of Georgia. Wageningen Academic Publishers, The Netherlands, 184 p.

Mahadevan, N., Shivali, K.P. (2009). Hibiscus sabdariffa Linn: An overview. Natural Product Radiance 8: 77-83.

Mir, B.G., Ravan, S. and Asgharipour, M., 2011. Effects of plant density and sowing date on yield and yield components of Hibiscus sabdariffa in Zabol region. Advances in Environmental Biology 5(6): 1156-1161.

Morton, J.F. (1987). Roselle. In Fruits of Warm Climates, ed. C.F. Dowling Jr. Media Inc., Greensboro, NC, USA, pp. 281- 286 .

Nnam, N.M. and Onyeke, N.G. (2003). Chemical composition of two varieties of sorrel (Hibiscus sabdariffa L.), calyces and the drinks made from them. Plant Foods Human Nutrition 58: 1-7.

Patil, K.B., (2004). Effect of various seed rates on yield of leafy vegetable sorrel. Journal of Soil and Crop Sciences 14(2): 461-462.

Perry, I.M. (1980). Medicinal plants of East and Southeast Asia. MIT Press, Cambridge.

Philip, C.B., Sajo, A.A. and Futuless, K.N. (2010). Effects of Spacing and NPK Fertilizer on Yield and Yield Components of Okra (Abelmoschus esculentus L.) in Mubi, Adamawa State, Nigeria. Journal of Agronomy 9(3): 131-134.

SAS inst. (2002). SAS (Statistical Analysis System), 1996 SAS/STAT. Guide Version 9. SAS, Institute Inc. Raleigh, North Carolina: USA.

Seiyaboh, E.I., Oku, I.Y. and Odogbo, O.M. (2013). Isolation and Identification Of Food-Borne Micro Flora From Zobo (A Nigerian Drink) Prepared From The Calyces Of Hibiscus Sabdariffa L. (Malvaceae). The International Journal of Engineering and Science 2: 2319 - 1805.

Singh, V.K. and Yadav, D.S. (1987). Effect of sowing date and row spacing on dwarf field sesame. Indian Journal of Agronomy 34(1): 92-95.

Tsai, P.J., Mc Intosh, J., Pearce, P., Camden, B. and Jordan, B.R., 2002. Anthocyanin and antioxidant capacity in Roselle (Hibiscus sabdariffa L.) extract. Food Research International 35: 351-356. 